\title{
Tris dešimtmečius vykstanti pasiryžimo ginti savo šali evoliucija: Baltijos šalių atvejis
}

Šiame straipsnyje pateikiama išsamiausia pasiryžimo ginti savo šali analizė panašiose ir kartu skirtingose Baltijos šalyse - Estijoje, Latvijoje ir Lietuvoje. Jame apžvelgiami ankstesni moksliniai tyrimai, kuriuose daugiausia dèmesio skiriama pasiryžimo ginti savo šalị dẻsningumo skirtumų aiškinimui. Šiame straipsnyje toliau pateikiami ankstesnių trijų šalių sociologinių tyrimų rezultatai ir aptariami šio tyrimo tikslais atliktos reprezentatyvios šalių apklausos rezultatai. Ankstesni ir dabartiniai duomenys rodo, kad estai labiau linkę ginti savo šalį, o latviai ir lietuviai ne tokie entuziastingi. Platesniame regioniniame ir pasauliniame kontekste Estijos gyventojų pasiryžimas ginti savo šali yra didelis, o Lietuvos - mažas.

Analizuojant Baltijos šalių duomenis, tikrinamos kelios hipotezės dèl dėsningumų. Patvirtinama, kad intersocialiniu lygmeniu galimybių gyvenime augimas paprastai turi neigiamą įtaką pasiryžimui ginti savo šalį, tačiau tuo negalima paaiškinti abiejų rodiklių svyravimo koreliacijos. Intrasocialiniu lygmeniu patvirtinama, kad vyrai labiau linkę ginti savo šali. Nors empiriniai duomenys, susiję su dviem Baltijos šalimis, patvirtina kai kurias kitas hipotezes, pavyzdžiui, tas, kurios susijusios su pasitikejimu ginkluotosiomis pajegomis, išorinių grèsmių poveikiu ir istorinėmis patirtimis, kiti veiksniai, tokie kaip pasitikẻjimas vyriausybe, religingumas, karo prievolè, amžius ar išsilavinimas, individualiu lygmeniu nẻra galutinai patvirtinami visose trijose šalyse. Tai pabrěžia ịvairių veiksnių svarbą, jų sąveiką ir skirtingą poveikị žmonių pasiryžimui ginti savo šalị.

\section{Ivadas}

Asmenų pasiryžimo ginti savo šalị klausimas išlieka aktualus nuolat kintančioje saugumo aplinkoje. Dèl visame pasaulyje paplitusių ginkluotų konfliktų šalies ir asmens saugumas tampa vis svarbesnis. Vis dèlto asmeninius prioritetus vis dažniau formuoja tradicinès ir besivystančios išorès ir vidaus dinamikos ịvairovè. Skaitmenizacijos plètra, skaitmeninès informacijos

\footnotetext{
"Dr. Māris Andžāns - Rygos Stradinio universiteto Europos studijų fakulteto asistentas. Adresas korespondencijai: Dzirciema iela 16, LV-1007 Rịga, Latvija; phone: +371 67409261; el. p. maris.andzans@rsu.lv

** Dr. Andris Sprūds - Rygos Stradinio universiteto Europos studijų fakulteto profesorius. Adresas korespondencijai: Dzirciema iela 16, LV-1007 Rīga, Latvija; phone: +371 67409261; el. p. andris.spruds@rsu.lv
} 
erdvės, kaip ginklo, pritaikymas ir ịtakos karų kampanijos gali iš esmės nulemti asmenų pasirinkimą, ypač nežinomybès laikotarpiu. Besivystančios visuomenès „širdys ir protai“ patiria kitų reikšmingų vidaus veiksnių poveikį, kuris turi ịtakos asmenų pasiryžimui ginti savo šalị. Tokie individualaus suvokimo ir loginio pagrindimo deriniai bei galutiniai pasirinkimai tiesiogiai siejami su šalių gynybos galimybėmis. Taigi asmenų pasiryžimas veikti yra ypač svarbus.

Pasiryžimas ginti savo šalį ir už ją kovoti kartu su tuo susijusiomis pažiūromis, tokiomis kaip pasiryžimas kariauti ir remti karą, plačiai tyrinètas politologu ir sociologų. Jis taip pat iš esmès sutapo su laipsniškai didejjančiu susidomejjimu saugumo ir gynybos tyrimų planais, daugiau dèmesio skiriant individualaus lygio ir jo suvokimo klausimams. Šiame straipsnyje daugiausiai dèmesio skiriama pasiryžimo ginti savo šalị ir kovoti už savo šalị, šias sąvokas pakaitomis vartojant Baltijos šalių kontekste, pažiūroms. Nors jau yra atlikta nemažai tyrimų, susijusių su pasiryžimu kariauti pažiūromis ir parama karui, kitose dalyse pateiksime siauresnę šių koncepcijų apžvalgą. Atliekant tokius tyrimus, be kita ko, pateikiamos išvados apie individualaus lygio prioritetu priežastingumą.

Kalbant apie pasiryžimą ginti savo šalì, pažymètina, kad literatūroje nemažai vietos skiriama pasaulinio ir (arba) regioninio lygio tyrimų metu gautu duomenų aiškinimui, ypatingą dèmesị skiriant Pasaulio vertybių apklausos tyrimui ${ }^{1}$ ir Europos vertybių tyrimui ${ }^{2}$. Su šiuo klausimu siejamus dèsningumus savo $2015 \mathrm{~m}$. straipsnyje išsamiausiai iqvertino Inglehartas, Puranenas ir Welzelas (toliau - Inglehartas ir kt.) ${ }^{3}$. Iš esmès šis straipsnis - atsakas ị jų raginimą tęsti tyrimus šioje srityje $e^{4}$. Jame dẻmesys sutelkiamas ị konkrečią tyrimų spragą - hipotezių ir prielaidų dèl priežastinių mechanizmų sintezès nustatymą ir jų tikrinimą, atliekant šiuo aspektu daugelio valstybių tyrimą, naudojant reprezentatyvius šalių empirinius duomenis.

Trys panašios ir kartu skirtingos Baltijos šalys - unikalus atvejis, vertas išsamios analizès. Pirma, per beveik tris dešimtmečius nuo išsilaisvinimo iš Sovietų Sąjungos ir nepriklausomybès atgavimo jos išgyveno didelę politinę, ekonominę ir visuomenès pertvarką: atkūrusios nepriklausomybę 1991 metais, ịstojo ị Europos Sąjungą (toliau - ES) ir NATO, prisijungė prie euro zonos

\footnotetext{
1 "Welcome to the World Values Survey site", Institute for Comparative Survey Research, accessed December 27, 2019, http://www.worldvaluessurvey.org

2 "European Values Study", accessed December 27, 2019, https://europeanvaluesstudy.eu

${ }^{3}$ Ronald F. Inglehart, Bi Puranen, and Christian Welzel, "Declining willingness to fight for one's country: The individual-level basis of the long peace", Journal of Peace Research 52, no. 4 (2015): 418-434.

${ }^{4}$ Inglehart et al., "Declining willingness to fight for one's country: The individual-level basis of the long peace", 432 .
} 
ir Šengeno erdvès. Joms pavyko integruotis į ES net geriau nei kitoms valstybėms narėms. Jos taip pat gerokai patobulejjo, vertinant ekonominę plètrą ir visuomenės laisves. Tai - solidus ir reprezentatyvus daugèjančiu galimybių gyvenime poveikio pasiryžimui ginti savo šalis vertinimo atvejis, kuris atsidūré Ingleharto ir kitų tyrèjų atlikto tyrimo centre.

Antra, visų trijų šalių santykiai su Rusija, kuri yra jų kaimynè, sudètingi. Daugelio manymu, Rusija ir yra pagrindinis pavojaus jų saugumui šaltinis ${ }^{5}$. Grèsmè tapo kur kas geriau suvokiama po $2008 \mathrm{~m}$. Rusijos ir Gruzijos karinio konflikto, o ypač prasidejus Rusijos ir Ukrainos konfliktui, kuris tęsiasi nuo 2014 metų. Nuo tada daugiau demesio skiriama individualios gynybos pajègumams (taip pat ir nekarinėse srityse), NATO sąungininkai visose trijose šalyse dislokavo karines pajègas rotacijos principu. Ankstesnèje šios srities literatūroje, ypač Ingleharto ir kitų ${ }^{6}$ teigiama, kad su kaimyninèmis šalimis siejama negatyvi saugumo dinamika laikoma veiksniu, stiprinančiu pasiryžimą ginti savo šali.

Trečia, nors visos trys šalys dažnai traktuojamos kaip tam tikras regioninis vienetas, jos tuo pat metu yra ir panašios, ir skirtingos. Kaip skirtumą galima paminèti tai, kad pastaraisiais dešimtmečiais Estija pateko ị Šiaurès šalių itakos zoną ir kartais vadino save Šiaurès (ne Baltijos) šalimi, o Lietuvą stipriau veikè Vidurio Europos įtaka. Visų trijų šalių požiūris ị savo ginkluotąsias pajègas skiriasi, įskaitant naujokų ėmimo praktiką, nes Estija remiasi karo prievole, o Lietuva neseniai grị̌zo prie švelnesnès jos formos. Svarbu ir tai, kad, palyginti su Lietuva, tiek Estijoje, tiek Latvijoje gyvena etniniu požiūriu heterogeninès visuomenès. Didelę jų gyventojų dalį sudaro rusai ir kitos rytų slavų kilmès žmonès ${ }^{7}$, tad jų pažiūros dažnai skiriasi nuo daugumos etninių estų ir latvių,

\footnotetext{
${ }^{5}$ Parliament of Estonia, National Security Concept of the Republic of Estonia (2017), http://www. kaitseministeerium.ee/sites/default/files/elfinder/article_files/national_security_concept_2017_0.pdf; Parliament of Latvia, The National Security Concept (2019), https://www.mod.gov.lv/sites/mod/files/ document/NDK_ENG_final.pdf; Parliament of Lithuania, National Security Strategy of the Republic of Lithuania (January 17, 2017), https://kam.lt/download/57457/2017-nacsaugstrategijaen.pdf

${ }^{6}$ Inglehart et al., "Declining willingness to fight for one's country: The individual-level basis of the long peace", 420.

${ }^{7}$ Estijos gyventojų sudètis 2019 m.: estai sudare 68,5 \%, rusai - 24,8 \% (as of 2019); Latvijos gyventojų sudètis 2019 m.: latviai sudare $62,3 \%$, rusai - 24,9\%, ukrainiečiai - 2, $2 \%$, lenkai - $2 \%$; Lietuvos gyventojų sudètis (2011 m. surašymo duomenys): lietuviai sudarė 84,2 \%, lenkai - 6,6 \%, rusai - 5,8 \% ("Population by ethnic nationality, 1 January, years", Statistics Estonia, 2019, modified June 6, 2019, https:// www.stat.ee/34278; "IRG069. Usually resident population by ethnicity at the beginning of the year", Central Statistical Bureau of Latvia, accessed December 27, 2019, http://data1.csb.gov.lv/pxweb/en/iedz/ iedz_iedzrakst/IRG069.px/; "Ethnicity, mother tongue and religion”, Statistics Lithuania, last modified March 15, 2013, https://osp.stat.gov.lt/en/web/guest/informaciniai-pranesimai?articleId=223122
} 
ịskaitant pažiūras dèl pasiryžimo ginti šalis, kuriose jie gyvena ${ }^{8}$. Nors šis aspektas buvo nagrinètas ankstesnių tyrimų, ypač neseniai atlikto Rutkausko tyrimo, metu ${ }^{9}$, šia prasme derètų nuodugniau panagrinèti visų trijų šalių atvejus.

\section{Hipotezès dèl pasiryžimo ginti savo šali}

\subsection{Ankstesnių tyrimų hipotezès}

Pasiryžimo kovoti už savo šali lygio aiškinimo sudètingumą akcentavo Díez-Nicolás „kaip militarizmo arba antimilitarizmo, kaip aukšto arba žemo lygio piliečių sąmoningumo ir atsakomybės arba kaip drąsos ir bailumo ženklus"10. Pabrěždami būtinybę siekti taikaus elgesio, sprendžiant tarpvalstybinius reikalus, nemanome, kad pasiryžimas ginti savo šalị yra savaime negatyvus ir militarizmo, panašumo ị karą ar agresyvumo požymis. Tai ypač pasakytina apie mažas šalis ir ne itin galingas valstybes. Be to, vyriausybès paprastai linkusios teigiamai vertinti pasiryžimą ginti atitinkamą šali ir siekia kelti tokios atsakomybès lygi nacionalinio saugumo sistemose ${ }^{11}$.

Šiame straipsnyje nenagrinëjama nei demokratinès taikos ${ }^{12}$, nei kapitalistinès taikos sampratos ${ }^{13}$, darant prielaidą, pirmuoju atveju - kad demokratijos beveik niekada nekovoja tarpusavyje, antruoju atveju - kad šiuolaikinių demokratijų klestejjimas ir tarpusavio priklausomybė lemia jų taikumą. Kitaip tariant, šio tyrimo objektas nèra veiksniai ir prielaidos, kurie prisideda prie konfliktų tarp valstybių, nes siekiama ịvertinti ir paaiškinti piliečių pasiryžimą kovoti už savo šalį iš gynybinès perspektyvos - kodèl žmonès yra arba nèra pasirenge ginti savo šalis išorinès agresijos atveju?

\footnotetext{
${ }^{8}$ Pavyzdžiui, Estijos ir Latvijos gynybos ministerijų apklausos: Turu-uuringute, Public Opinion and National Defence, March 2019, http://www.kmin.ee/sites/default/files/elfinder/article_files/public_ opinion_and_national_defence_2019_march_0.pdf, 39; SKDS, Latvijas iedzīvotāju viedoklis par valsts aizsardzības jautäjumiem, November 2016, https://www.mod.gov.lv/sites/mod/files/document/SKDS_ aptauja_2016\%20\%281\%29.pdf, 43.

${ }^{9}$ Virgilijus Rutkauskas, "Factors Affecting Willingness to Fight for One's Own Country: The Case of Baltic States", Special Operations Journal 4, no. 1 (2018): 48-62.

${ }^{10}$ Juan Díez-Nicolás, "Cultural Differences on Values about Conflict, War and Peace", in Religion, democratic values and political conflict, ed. Yilmaz Esmer, Hans-Dieter Klingemann, and Bi Puranen (Uppsala University, 2009): 259.

${ }^{11}$ Pvz., žr: Parliament of Lithuania, National Security Strategy of the Republic of Lithuania, 15.

${ }_{12}$ Žr.: Michael W. Doyle, "Liberalism and world politics", American Political Science Review 80, no. 4 (1986): 1151-69.

${ }^{13}$ Žr.: Richard Rosecrance, The Rise of the Trading State: Commerce and Conquest in the Modern World (New York: Basic Books, 1987).
} 
Išsamiausią tyrimą šioje srityje atliko ir pateike bendrus ir individualius svarstymus Inglehartas ir kiti. Jie iškèle ir patikrino keturias hipotezes, pagrịstas Pasaulio vertybiu apklausos tyrimo ir Europos vertybių tyrimo metu surinktais duomenimis. Pirma, skerspjūvio aspektu, daugiau galimybių gyvenime turinčios ir aukštesni egzistencinio saugumo lygi jaučiančios visuomenès pabrèžia pasirinkimo galimybes palaikančias vertybes (vertinamas kaip paramą reprodukcinèms laisvèms ir homoseksualumui), bet demonstruoja ne tokị tvirtą pasiryžimą karuose rizikuoti savo gyvybèmis. Antra, išilginiu aspektu, kuo labiau visuomenejje ịsitvirtina pasirinkimo galimybes palaikančios vertybės, tuo staigiau menksta pasiryžimas rizikuoti savo gyvybemis. Trečia, daugiapakopiu aspektu, visuomenès, kuriose labiau paplitusios pasirinkimo galimybes palaikančios vertybès, stumia ị pavojingas situacijas tuos savo narius, kuriems būdingas žemesnis pasiryžimo lygis. Ketvirta, istoriniu aspektu, dèl praeityje patirto pažeminimo karuose sumažěja pasiryžimas kovoti (nagrinèdami šią hipotezę, jie taip pat mini Šiaurès šalių reiškinị, kurị toliau nagrinèsime atskirai). Apskritai Inglehartas ir kt. teigia, kad didesnès galimybès gyvenime prisideda prie didesnio gyvybių vertinimo ir atitinkamai lemia menkesnị pasiryžimą rizikuoti gyvybemis ${ }^{14}$.

Pirmąsias dvi ir ketvirtają Ingleharto ir kt. hipotezes galima priskirti intersocialinei kategorijai, t. y. jose daromos dėsningumų visuomenès (valstybès) lygmeniu prielaidos ir siekiama paaiškinti, kodèl tam tikroms visuomenèms būdingas aukštesnis arba žemesnis pasiryžimo kovoti lygis. Trečiosios jų hipotezès dèmesio centre yra intrasocialinis, arba individualusis, lygmuo veiksniai, kurie turi ịtakos ịvairioms visuomenèms priklausančių asmenų pasirinkimui. Abiejų tipų hipotezės viena kitai neprieštarauja. Pavyzdžiui, aukštą nacionalinio pasididžiavimo lygi galima laikyti abiejų jų prognozavimo rodikliu. Toliau argumentuojant teigiama, kad aukštesnis visuomenių nacionalinio pasididžiavimo lygis tikriausiai bus susijęs su tvirtesniu pasiryžimu kovoti už savo šalį, o didesnị nacionalinị pasididžiavimą jaučiantys asmenys bus labiau pasiryžę tai daryti, nei tautiečiai, kurie ne taip palankiai vertina savo šali.

Yra dar pora kitų intersocialinių hipotezių, kurioms vertètų skirti daugiau dèmesio. Remdamasis Pasaulio vertybių apklausos tyrimo ir Europos vertybių tyrimo informacija (nuo 1981 iki 2005 m.), Diez-Nicolas daro išvadą, kad nacionalinio pasididžiavimo (ir pasitikèjimo nacionalinėmis ginkluotosiomis pajègomis) lygis yra tiksliausias pasiryžimo kovoti už savo šalị prognozavimo rodiklis - kuo didesnis nacionalinis pasididžiavimas ir pasitikèjimas nacionalinėmis ginkluotosiomis pajègomis, tuo tvirtesnis būtų pasiryžimas kovo-

\footnotetext{
${ }^{14}$ Inglehart et al., "Declining willingness to fight for one's country: The individual-level basis of the long peace”, 418, 421-2.
} 
ti už atitinkamą šalị, jei kiltų karas. Pasak jo, ši tendencija pastebima šalyse, kurioms būdingi dideli skirtumai, ir paprastai ji ilgai išlieka stabili ${ }^{15}$. Taip pat Puranenas ir Torgleras akcentuoja tvirtą sąsają tarp nacionalinio pasididžiavimo ir pasitikejimo ginkluotosiomis pajègomis lygių bei pasiryžimo kovoti. Vis dèlto abu pabrèžia šią tendenciją individualiu, o ne šalies lygmeniu; Torgleras teigia, kad šiuo atžvilgiu pasitikejimas vyriausybe ir teisès sistemomis taip pat rodo aukštesnị pasiryžimo kariauti lygi ${ }^{16}$.

Kelių tyrimų išvadose taip pat pažymima, kad pasiryžimas kovoti už savo šali labai priklauso nuo tos šalies istorinio, socialinio ir politinio konteksto. Ankstesnių tyrimų, taip pat Ingleharto ir kitų (jų ketvirtoji hipotezė dèl istorinès perspektyvos), metu buvo nustatyta, kad dvi šaliu grupès ypač išsiskiria iš kitų. Šios dvi grupès yra Antrojo pasaulinio karo ašių galingosios valstybès, ypač Vokietija ir Japonija, ir Šiaurès šalys. Pirmosios grupès pasiryžimas kovoti yra nedidelis ${ }^{17}$, o antrosios - didesnis, nei būtų galima prognozuoti remiantis kitomis hipotezemis ir rodikliais ${ }^{18}$.

Inglehartas ir kt., taip pat Puranenas nuodugniau nagrinëja Šiaurès šalių reišskinị. Jie tai aiškina emancipaciniu Šiaurès šalių visuomenių gyvenimo būdu ir tai, kad jos yra netoli nuo Rusijos (buvusios Sovietų Sajungos, keliančios grèsmę jų gyvenimo būdui); ${ }^{19}$ taigi Šiaurès šalių gynyba siejama su regione dominuojančiu vertybių gynyba ir propagavimu ${ }^{20}$. Díez-Nicolás taip pat pažymėjo, kad ịsitraukimas ị vykstančius konfliktus ir išorines grèsmes gali pakelti pasiryžimo kovoti už šalį lygį ${ }^{21}$.

Horowitzas ir Levenduskis ịvertino karo prievolès poveiki paramos karui aspektu (ši veiksnị derètų panagrinèti, taikant skirtingus metodus ir rengiant diskusijas šiuo klausimu, tiriant Baltijos šalių atvejî). Kadangi jų išvados pagrịstos tik vienoje šalyje, Jungtinèse Amerikos Valstijose, atliktu eksperi-

\footnotetext{
${ }^{15}$ Díez-Nicolás, “Cultural Differences on Values about Conflict, War and Peace”, 264, 272.

${ }^{16}$ Bi Puranen, "Allegiance eroding: People's dwindling willingness to fight in wars", in The Civic Culture Transformed: From Allegiant to Assertive Citizens, ed. Russell J. Dalton, and Christian Welzel (New York: Cambridge University Press, 2015), 269, 276-7; Benno Torgler, "Why do people go to war?", Defence and Peace Economics 14, no. 4 (2003): 276.

${ }^{17}$ Inglehart et al., "Declining willingness to fight for one's country: The individual-level basis of the long peace”, 420, 428; Bi Puranen, “Allegiance eroding: People’s dwindling willingness to fight in wars”, 271; Díez-Nicolás, "Cultural Differences on Values about Conflict, War and Peace", 265; Torgler, "Why do people go to war?” 276; Christopher J. Anderson, Anna Getmansky, and Sivan Hirsch-Hoefler, "Burden sharing: income, inequality and willingness to fight”, British Journal of Political Science (2018): 32.

${ }^{18}$ Inglehart et al., "Declining willingness to fight for one's country: The individual-level basis of the long peace", 420, 428; Bi Puranen, "Allegiance eroding: People’s dwindling willingness to fight in wars", 271; Torgler, "Why do people go to war?", 276.

${ }^{19}$ Inglehart et al., "Declining willingness to fight for one's country: The individual-level basis of the long peace", 420 .

${ }^{20}$ Bi Puranen, "Allegiance eroding: People's dwindling willingness to fight in wars", 271.

${ }^{21}$ Díez-Nicolás, "Cultural Differences on Values about Conflict, War and Peace", 259, 261-2, 264.
} 
mentu, šiuos rezultatus derètų vertinti atsargiai. Jie daro išvadą, kad privaloma tarnyba sumažina visuomenès paramą karams. Anot šių autorių, labiausiai tikètinas paaiškinimas yra žmonių asmeniniai interesai, kitaip tariant, nenoras rizikuoti savo, kaip šauktinių, gyvybe ${ }^{22}$. O Andersonas ir kt., remdamiesi Horowitzo ir Levenduskio straipsniu, pažymi, kad pasiryžimo kovoti lygis yra šiek tiek aukštesnis šalyse, kuriose ịvesta karo prievolè²3.

Regioninis, kultūrinis, socialinis ir ekonominis kontekstai taip pat buvo vertinami kaip veiksniai, lemiantys žemesnị arba aukštesnị pasiryžimo ginti savo šalị lygì. Díez-Nicolás padare išvadą, kad didžiausias pasiryžimas kovoti pastebimas (pagal jo paties apibrěžimą) Azijos Kinijos Konfucijaus, islamo ir ị pietus nuo Sacharos esančiose šalyse, o žemiausias jo lygis nustatytas Vakarų Europos katalikiškose ir anglosaksų šalyse (Baltijos šalis jis priskyrẻ Vakarų Europos protestantų šalių, kuriose iš esmès matomas vidutinis pasiryžimo kovoti lygis, kategorijai) ${ }^{24}$. 2014 m. WIN/ „Gallup International“ atlikus pasaulinę apklausą, padaryta išvada, kad daugiausiai pasiryžę kovoti už savo šalị yra gyvenantys bendrame Vidurinių Rytų ir Šiaurès Afrikos regione bei Azijoje (taip pat musulmonai ir induistai, pagal religinius ịsitikinimus), o mažiausiai - Vakarų Europos ir Šiaurès Amerikos (taip pat tarp protestantų) gyventojai ${ }^{25}$. Be to, Andersonas ir kt. padare išvadą, kad visuomenès, kurios narių pajamų nelygybė yra didesnè, pasiryžimas kovoti už savo šali yra menkesnis, palyginti su šalimis, kuriose nelygybès lygis yra žemesnis ${ }^{26}$.

Atliekant tyrimus, kuriuose demesys buvo sutelktas ị intrasocialinị arba individualų lygmenį, dažnai pastebėta, kad tokie rodikliai kaip lytis ir požiūris ị šalị yra reikšmingi veiksniai, lemiantys asmens pasiryžimą kovoti. Nors atliekant ịvairius tyrimus (ypač i konkrečius regionus orientuotus) paprastai padaromos skirtingos išvados dèl tam tikrų rodiklių, daugeliu atvejų paaiškẻja, kad vyrai labiau linkę kovoti nei moterys ${ }^{27}$ (kai kuriuose tyrimuose taip pat akcentuojamas jaunesnis amžius ${ }^{28}$ ir šeiminè padetis ${ }^{29}$ ), o asmenys, kurių na-

\footnotetext{
${ }^{22}$ Michael C. Horowitz and Matthew S. Levendusky, "Drafting Support for War: Conscription and Mass Support for Warfare", The Journal of Politics 73, no. 2, (May 2011): 532.

${ }^{23}$ Anderson et al., "Burden sharing: income, inequality and willingness to fight", 32.

${ }^{24}$ Díez-Nicolás, "Cultural Differences on Values about Conflict, War and Peace", 262.

${ }^{25}$ WIN/Gallup International, WIN/Gallup International Global Survey Shows Three in Five Willing to Fight for Their Country, March 18, 2015, http://gallup.com.pk/wp-content/uploads/2015/12/1803151.pdf, 3.

${ }^{26}$ Anderson et al. "Burden sharing: income, inequality and willingness to fight", 30-1.

${ }^{27}$ Inglehart et al., "Declining willingness to fight for one's country: The individual-level basis of the long peace", 28 (appendix); Torgler, "Why do people go to war?" 276; Bi Puranen, "Allegiance eroding: People's dwindling willingness to fight in wars", 277; WIN/Gallup International, WIN/Gallup International Global Survey Shows Three in Five Willing to Fight for Their Country, 1.

${ }^{28}$ WIN/Gallup International, WIN/Gallup International Global Survey Shows Three in Five Willing to Fight for Their Country, 1; Torgler, "Why do people go to war?", 276.

${ }^{29}$ Anderson et al., "Burden sharing: income, inequality and willingness to fight", 31.
} 
cionalinio pasididžiavimo jausmas stipresnis ir pasitikejimas ginkluotosiomis pajègomis didesnis, yra pasiryžę kovoti ${ }^{30}$ (be to, kai kurie taip pat pažymi, kad tai susiję su pasitikejimu vyriausybe ir teisine sistema bei religingumu ir ideologiniu polinkiu palaikyti dešiniuosius ${ }^{31}$. Nors išsilavinimo lygis dažnai yra minimas kaip veiksnys, lemiantis asmenų požiūrị šiuo atžvilgiu, Andersonas ir kiti pažymi, kad trūksta įrodymų, patvirtinančių ryši tarp asmenų išsilavinimo lygio ir pasiryžimo kovoti už šalį̧

Kituose literatūros šaltiniuose įvertintas socialinių ir ekonominių veiksnių poveikis asmenų pasirinkimui. Andersonas ir Hirsch-Hoefleris ${ }^{33}$ ir kt. ịvertino sąsają tarp ekonominès lygybès ir pasiryžimo kovoti. Atlikus pastarąji tyrimą, remiantis Pasaulio vertybių apklausos tyrimo duomenimis (1981-2013 m.), padaryta išvada, kad visuomenèse, kuriose nelygybès lygis yra žemas, nenustatyta skirtumo tarp turtingụjų ir skurdžiai gyvenančių asmenų pasiryžimo kovoti, tačiau, didejjant nelygybei visuomenejje, turtingų žmonių pasiryžimas kovoti mažẻja, palyginti su skurdžiai gyvenančiaisiais (jų manymu, skurdžiau gyvenantys žmonès labiau linkę mobilizuotis kovai) ${ }^{34}$. Galiausiai Torgleris ịvertino naudos ir sąnaudų skirtumo poveiki pasiryžimui kariauti. Jam nepavyko rasti pakankamai ịrodymų, patvirtinančių, kad naudos ir sąnaudų skaičiavimai turi didelę itaką asmenų pasirinkimui. Kitaip tariant, asmenų pasirinkimas kariauti yra neracionalus ${ }^{35}$.

\subsection{Hipotezių sintezè}

Šioje straipsnio dalyje apibendrinami ankstesniame skyrelyje pateikti svarstymai, o hipotezès suskirstomos ị dvi kategorijas, siekiant jas toliau taikyti aptariant Baltijos šalių atvejị. Kaip jau minèta, kadangi kai kurie abiejų kategorijų elementai iš dalies sutampa su tuo pačiu veiksniu, tai gali turèti ịtakos situacijai tiek intersocialiniu, tiek intrasocialiniu lygmeniu. Skiriasi analizès, pagal

\footnotetext{
${ }^{30}$ Inglehart et al., "Declining willingness to fight for one's country: The individual-level basis of the long peace", 28 (appendix); Bi Puranen, "Allegiance eroding: People's dwindling willingness to fight in wars", 277; Torgler, "Why do people go to war?", 276; Anderson et al. "Burden sharing: income, inequality and willingness to fight", 5, 31-2.

${ }^{31}$ Torgler, "Why do people go to war?", 276.

${ }^{32}$ Anderson et al., "Burden sharing: income, inequality and willingness to fight", 32.

${ }^{33}$ Christopher J. Anderson, and Sivan Hirsch-Hoefler, "UNEQUAL SACRIFICE: Income, Inequality, and the Willingness to Fight Wars", Paper prepared for presentation at the Annual Meeting of the American Political Science Association, Washington, DC, September 2-5, 2010: 1-37, https://papers.ssrn.com/sol3/ papers.cfm?abstract_id $=1644044 \# \#$

${ }^{34}$ Anderson et al., "Burden sharing: income, inequality and willingness to fight", 30-1.

${ }^{35}$ Torgler, "Why do people go to war?", 261, 276.
} 
kurią keliamos šios hipotezès, kontekstas ir dèmesio centras. Vis dèlto, mūsų manymu, toks duomenų rinkimo metodas gali palengvinti tolesnį tyrimą.

Pirma, pateikiame intersocialinio arba šalies lygmens hipotezes (H.1.[nuosekli numeracija]), kurias siekiama patikrinti šiame straipsnyje:

- H.1.1: Visuomenès, kurių narių galimybès gyvenime yra didesnès, pabrèžia pasirinkimo galimybes palaikančias vertybes ir demonstruoja menkesnị pasiryžimą kovoti.

- H.1.2: Visuomenès, kurių narių nacionalinio pasididžiavimo, pasitikejimo nacionalinemis ginkluotosiomis pajegomis ir vyriausybe lygis yra aukštesnis, demonstruoja aukštesnio lygio pasiryžimą kovoti.

- H.1.3: Visuomenès, kurios patyrè pažeminimą ankstesnių karų metu, demonstruoja menkesni pasiryžimą kovoti, o visuomenès, kurios susiduria su dabartinèmis išorinèmis grésmèmis, - aukštesnio lygio pasiryžimą kovoti.

- H.1.4: Visuomenès, kuriose vyrauja didesnè pajamų nelygybè, demonstruoja menkesnị pasiryžimą kovoti.

Antra, šios intrasocialinio arba individualaus lygmens hipotezès (H.2.[nuosekli numeracija]) tikrinamos, remiantis empiriniais įrodymais:

- H.2.1: Vyrai, kurių nacionalinio pasididžiavimo jausmas ir pasitikejjimas savo nacionalinemis ginkluotosiomis pajëgomis ir vyriausybe yra aukštesnio lygio, demonstruoja aukštesnio lygio pasiryžimą kovoti.

- H.2.2: Kai yra didesnè pajamų nelygybė, visuomenès turtingieji yra mažiau pasiryžę kovoti, nei skurdžiai gyvenantys asmenys.

- H.2.3: Asmenų pasirinkimas kovoti yra neracionalus, vertinant jo sąnaudas ir naudą.

Nors veiksniai, susiję su religingumu, amžiumi, išsilavinimu, ideologinèmis pažiūromis ir karo prievole, taip pat buvo nagrinèti ankstesniame skyrelyje, šios išvados nèra pakankamai aiškiai paskirstytos pasiryžimo ginti šali tyrimo plane, todèl nepatenka ị šio tyrimo dèmesio centrą. Nepaisant to, atsižvelgiant $\mathfrak{i}$ turimus duomenis, šie veiksniai bus apžvelgiami paskutiniame šio straipsnio skyriuje. 


\section{Pasiryžimas ginti Baltijos šalis istoriniu ir šiuolaikiniu požiūriu}

\subsection{Istorinè raida}

Pasiryžimas ginti Baltijos šalis buvo nagrinejjamas atliekant daugelị sociologinių apklausų ir jų analizių. Platesniame pasaulio ir regiono (šiuo atveju - Europos) kontekste šis klausimas itin plačiai nagrinètas, atliekant Pasaulio vertybių apklausos tyrimą ir Europos vertybių tyrimą. Abiejuose pateikti nuoseklūs duomenys, pagrịsti bendrai sutartais klausimais (kurie užduodami respondentams). Tuo pačiu metu, atlikus abi apklausas, gauti istoriškai suskaidyti duomenys apie tris studijuojamas šalis. Paskutinị kartą apklausa visose trijose šalyse tuo pat metu buvo atlikta 1990 m., kai jos oficialiai vis dar priklausė Sovietų Sajungai.

Iš mokslinių tyrimų, orientuotų i Baltijos šalis, $2018 \mathrm{~m}$. Rutkausko atliktame tyrime pateikta išsamiausia ir naujausia šio klausimo apžvalga. Jo atlikta duomenų analizè, apimanti laikotarpị nuo 1990 m. iki 2015 m., rodo, kad pasiryžimą kovoti už Baltijos šalis dažniausiai lemia nacionalinis pasididžiavimas, pasitikejjimas atitinkamomis vyriausybèmis ir nacionalinèmis ginkluotosiomis pajegomis bei pasitenkinimas šalies finansine situacija (jis padarè šias išvadas, remdamasis 1990 m. ir 2011 m. duomenimis apie Estiją, 1990 m., 1997 m. ir 2014 m. duomenimis apie Latviją ir 1990 m., 1997 m., 1999 m., 2005 m., 2010 m., 2014 m. ir 2015 m. duomenimis apie Lietuvą) $)^{36}$. Atliekant kitus mokslinius tyrimus, orientuotus ị Baltijos šalis (vienos šalies, dvišalius arba trišalius), šis klausimas buvo nagrinètas platesniame kontekste. Vileikienè ir Janušauskienė apibendrino ir išanalizavo duomenis apie Lietuvą nuo 1990 m. iki 2016 m. Lietuvos visuomenès saugumo suvokimo kontekste ${ }^{37}$, Andžāns, Sprūds ir Bruǵe (toliau - Andžāns ir kt.) ištyrè pasiryžimą ginti Latviją, remdamiesi 2017 m. apklausos duomenimis, psichologinès gynybos kontekste ${ }^{38}, 2017 \mathrm{~m}$. Ramonaitè, Petronytė-Urbonavičienè, Skirkevičius ir Vosylius (toliau - Ramonaitè ir kt.) ịvertino pasiryžimą ginti Lietuvą pilietinio pasipriešinimo kontekste ${ }^{39}$.

1 paveikslèlyje pateikti viešai skelbiami 1990-2019 m. duomenys: $1990 \mathrm{~m}$.

\footnotetext{
${ }^{36}$ Rutkauskas, "Factors Affecting Willingness to Fight for One's Own Country: The Case of Baltic States", 54-5.

${ }^{37}$ Eglè Vileikienè, and Diana Janušauskienè, "Subjective Security in a Volatile Geopolitical Situation: Does Lithuanian Society Feel Safe?", Journal on Baltic Security 2, no. 2 (2016): 126.

${ }^{38}$ Māris Andžāns, Ilvija Bruğe and, Andris Sprūds, Psiholoǵiskā aizsardzība Latvijā: ievainojamības un iespējas (Riga: Latvian Institute of International Affairs, 2017), 17.

${ }^{39}$ Ainè Ramonaitè, Leva Petronytė-Urbonavičienè, Paulius Skirkevičius, and Eugenijus Vosylius, Kas eitu ginti Lietuvos?: pilietinio pasipriešinimo prielaidos ir galimybès (Vilnius: Aukso žuvys, 2018).
} 
Europos vertybių tyrimo duomenys apie visas tris Baltijos šalis ${ }^{40}$ ir 1999 m. duomenys apie Lietuvą ${ }^{41} ; 1996$ m. Pasaulio vertybių apklausos tyrimo duomenys apie Estiją ir Latviją; 1997 m. duomenys apie Lietuvą ${ }^{42}$ ir 2011 m. duomenys apie Estiją $^{43} ; 2010$ m. „Spinter tyrimai“ apklausos duomenys apie Lietuvą ${ }^{44} ; 2014$ m. Pilietinès galios indekso apklausos duomenys apie Lietuvą ${ }^{45} ; 2016$ m. Subjektyvaus saugumo kintančiame geopolitiniame kontekste: ypatumų, formuojančių veiksnių ir individų kuriamų strategijų projekto apklausos duomenys apie Lietuvą ${ }^{46}$; Estijos gynybos ministerijos nuo 2000 m. iki 2019 m. atliktų apklausų (jas atliko „Turu-uuringute“, „Faktum uuringukeskus“ ir „Saar Poll“) duomenys apie Estiją ${ }^{47} ; 2014$ m. WIN/ „Gallup International“ visuotinès ap-

\footnotetext{
${ }^{40}$ European Values Study, EVS 1990 - Variable Report Integrated Dataset (European Values Study and GESIS Data Archive for the Social Sciences), released September 30, 2013, http://dx.doi.org/ doi:10.4232/1.10790, 561.

${ }^{41}$ European Values Study, EVS 1999 - Variable Report Integrated Dataset, https://dbk.gesis.org/dbksearch/ file.asp?file=ZA3811_cdb.pdf, 916.

42 "WVS Wave 3 (1995-1998)", World Values Survey (edited by Ronald F. Inglehart et al.; Madrid:

JD Systems Institute), last accessed December 27, 2019, http://www.worldvaluessurvey.org/

WVSDocumentationWV3.jsp.

43 "WVS Wave 6 (2010-2014)", World Values Survey (edited by Ronald F. Inglehart et al.; Madrid:

JD Systems Institute), last accessed December 27, 2019, http://www.worldvaluessurvey.org/

WVSDocumentationWV6.jsp.

${ }^{44}$ Darius Sutkus, "Pilietis-gynejas: norai ir galimybės", Karys 2053, no. 1 (2017): 31.

${ }^{45}$ The Civic Empowerment Index, http://www.civitas.lt/wp-content/uploads/2015/11/Summary_2014_PGI_

ENG-summary.pdf, 9.

${ }^{46}$ Vileikienè, and Janušauskienė, "Subjective Security in a Volatile Geopolitical Situation: Does Lithuanian Society Feel Safe?", 126.

${ }^{47}$ Turu-uuringute, Avalik arvamus ja riigikaitse, February 2001,

http://www.kmin.ee/sites/default/files/elfinder/article_files/avalik_arvamus_ja_riigikaitse_veebruar_2001. pdf, 9; Turu-uuringute, Avalik arvamus ja riigikaitse, June 2001,

http://www.kmin.ee/sites/default/files/elfinder/article_files/avalik_arvamus_ja_riigikaitse_juuni_2001.pdf, 8; Turu-uuringute, Avalik arvamus ja riigikaitse, October 2001,

http://www.kmin.ee/sites/default/files/elfinder/article_files/avalik_arvamus_ja_riigikaitse_oktoober_2001. pdf, 8;

Turu-uuringute, Avalik arvamus ja riigikaitse, March 2002, http://www.kmin.ee/sites/default/files/elfinder/ article_files/avalik_arvamus_ja_riigikaitse_marts_2002.pdf, 8;

Turu-uuringute, Avalik arvamus ja riigikaitse, June 2002,

http://www.kmin.ee/sites/default/files/elfinder/article_files/avalik_arvamus_ja_riigikaitse_juuni_2002.pdf, 7; Turu-uuringute, Avalik arvamus ja riigikaitse, October 2002,

http://www.kmin.ee/sites/default/files/elfinder/article_files/avalik_arvamus_ja_riigikaitse_oktoober_2002.

pdf, 9;

Faktum Uuringukeskus, Avalik arvamus ja riigikaitse, February 2003,

http://www.kmin.ee/sites/default/files/elfinder/article_files/avalik_arvamus_ja_riigikaitse_veebruar_2003.

pdf, 12;

Faktum Uuringukeskus, Avalik arvamus ja riigikaitse, May/June 2003,

http://www.kmin.ee/sites/default/files/elfinder/article_files/avalik_arvamus_ja_riigikaitse_juuni_2003. pdf, 11;

Faktum Uuringukeskus, Avalik arvamus ja riigikaitse, October 2003,

http://www.kmin.ee/sites/default/files/elfinder/article_files/avalik_arvamus_ja_riigikaitse_oktoober_2003. pdf, 12;
} 
Faktum Uuringukeskus, Avalik arvamus ja riigikaitse, February 2004,

http://www.kmin.ee/sites/default/files/elfinder/article_files/avalik_arvamus_ja_riigikaitse_veebruar_2004. pdf, 36;

Faktum Uuringukeskus, Avalik arvamus ja riigikaitse, June 2004,

http://www.kmin.ee/sites/default/files/elfinder/article_files/avalik_arvamus_ja_riigikaitse_juuni_2004.pdf, 37; Faktum Uuringukeskus, Avalik arvamus ja riigikaitse, October 2004,

http://www.kmin.ee/sites/default/files/elfinder/article_files/avalik_arvamus_ja_riigikaitse_oktoober_2004. pdf, 21;

Faktum Uuringukeskus, Avalik arvamus ja riigikaitse, March 2005,

http://www.kmin.ee/sites/default/files/elfinder/article_files/avalik_arvamus_ja_riigikaitse_marts_2005.pdf, 41; Faktum Uuringukeskus, Avalik arvamus ja riigikaitse, June 2005,

http://www.kmin.ee/sites/default/files/elfinder/article_files/avalik_arvamus_ja_riigikaitse_juuni_2005.pdf, 41;

Faktum Uuringukeskus, Avalik arvamus ja riigikaitse, November 2005,

http://www.kmin.ee/sites/default/files/elfinder/article_files/avalik_arvamus_ja_riigikaitse_novem-

ber_2005.pdf, 51; Turu-uuringute, Avalik arvamus ja riigikaitse, May 2006,

http://www.kmin.ee/sites/default/files/elfinder/article_files/avalik_arvamus_ja_riigikaitse_mai_2006.pdf, 31;

Turu-uuringute, Avalik arvamus ja riigikaitse, October 2006,

http://www.kmin.ee/sites/default/files/elfinder/article_files/avalik_arvamus_ja_riigikaitse_oktoober_2006. pdf, 31;

Turu-uuringute, Avalik arvamus ja riigikaitse, December 2006,

http://www.kmin.ee/sites/default/files/elfinder/article_files/avalik_arvamus_ja_riigikaitse_detsem-

ber_2006.pdf, 42; Turu-uuringute, Avalik arvamus ja riigikaitse, January 2007,

http://www.kmin.ee/sites/default/files/elfinder/article_files/avalik_arvamus_ja_riigikaitse_jaanuar_2007.

pdf, 31;

Turu-uuringute, Avalik arvamus ja riigikaitse, July 2007,

http://www.kmin.ee/sites/default/files/elfinder/article_files/avalik_arvamus_ja_riigikaitse_juuli_2007.pdf, 35; Turu-uuringute, Avalik arvamus ja riigikaitse, August 2008,

http://www.kmin.ee/sites/default/files/elfinder/article_files/avalik_arvamus_ja_riigikaitse_august_2008.pdf, 29; Turu-uuringute, Avalik arvamus ja riigikaitse, January 2009,

http://www.kmin.ee/sites/default/files/elfinder/article_files/avalik_arvamus_ja_riigikaitse_jaanuar_2009. pdf, 25;

Turu-uuringute, Avalik arvamus ja riigikaitse, May 2009,

http://www.kmin.ee/sites/default/files/elfinder/article_files/avalik_arvamus_ja_riigikaitse_mai_2009.pdf, 28; Turu-uuringute, Avalik arvamus ja riigikaitse, January 2010,

http://www.kmin.ee/sites/default/files/elfinder/article_files/avalik_arvamus_ja_riigikaitse_jaanuar_2010. pdf, 27;

Turu-uuringute, Avalik arvamus ja riigikaitse, September 2010,

http://www.kmin.ee/sites/default/files/elfinder/article_files/avalik_arvamus_ja_riigikaitse_septem-

ber_2010.pdf, 36; Turu-uuringute, Avalik arvamus ja riigikaitse, August 2011,

http://www.kmin.ee/sites/default/files/elfinder/article_files/avalik_arvamus_ja_riigikaitse_august_2011.

pdf, 30;

Saar Poll, Avalik arvamus ja riigikaitse, October 2011,

http://www.kmin.ee/sites/default/files/elfinder/article_files/avalik_arvamus_ja_riigikaitse_oktoober_2011.

pdf, 27;

Saar Poll, Public Opinion and National Defence, March 2012,

http://www.kmin.ee/sites/default/files/elfinder/article_files/public_opinion_and_national_defence_2012_ march.pdf, 29; Saar Poll, Avalik arvamus ja riigikaitse, October 2012,

http://www.kmin.ee/sites/default/files/elfinder/article_files/avalik_arvamus_ja_riigikaitse_oktoober_2012. pdf, 30;

http://www.kmin.ee/sites/default/files/elfinder/article_files/public_opinion_and_national_defence_2013_ oct.pdf, 30; Saar Poll, Public Opinion and National Defence, March 2014, http://www.kmin.ee/sites/ default/files/elfinder/article_files/public_opinion_and_national_defence_2014_march.pdf, 29; Turuuuringute, Public Opinion and National Defence, November 2014,

http://www.kmin.ee/sites/default/files/elfinder/article_files/public_opinion_and_national_defence_2014_ nov_0.pdf, 28; Turu-uuringute, Public Opinion and National Defence, October 2016, http://www.kmin. ee/sites/default/files/elfinder/article_files/public_opinion_and_national_defence_2016_october.pdf, 29; Turu-uuringute, Public Opinion and National Defence, autumn 2018, 
klausos duomenys apie Latviją ${ }^{48}$, Latvijos gynybos ministerijos nuo 2014 m. iki 2016 m. atliktų apklausų (jas atliko SKDS) duomenys apie Latviją ${ }^{49}, 2017$ m. Andžāns ir kt. (ją atliko SKDS) apklausos duomenys apie Latviją ${ }^{50} ; 2017 \mathrm{~m}$. Ramonaites ir kt. apklausos duomenys apie Lietuvą ${ }^{51} ; 2019 \mathrm{~m}$. šio tyrimo tikslais atliktos apklausos (ją atliko „Turu-uuringute“, SKDS ir „Baltijos tyrimai“) duomenys apie visas tris šalis.

Lyginant su Rutkausko pristatytu Baltijos šalių požiūriu, 1 paveikslèlyje pateikiami 42 apklausų, atliktų Estijos gynybos ministerijai (nuo 2000 m. iki 2019 m.), 3 apklausų, atliktų Latvijos gynybos ministerijai (nuo $2014 \mathrm{~m}$. iki 2016 m.), Andžāns ir kt. atlikto tyrimo (2018 m.) vienos apklausos, taip pat dèl šio tyrimo atliktos apklausos duomenys.

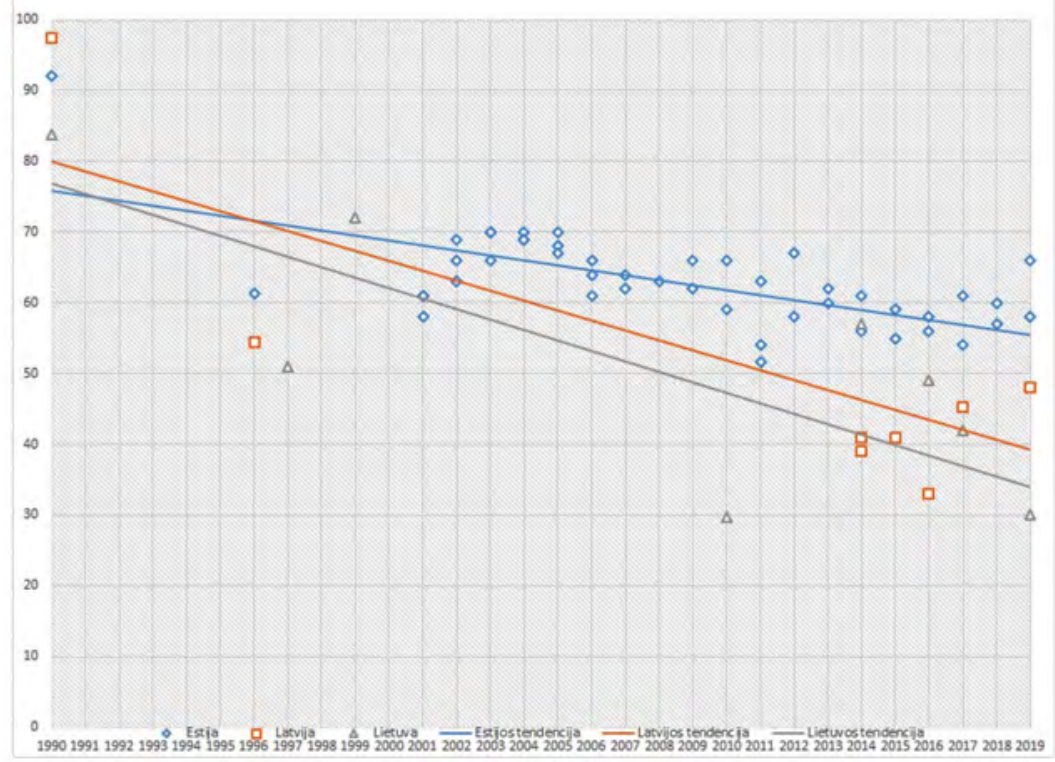

1 pav. Pasiryžimas ginti savo šali Estijoje, Latvijoje ir Lietuvoje ${ }^{52}$

\footnotetext{
${ }^{47} \mathrm{http}: / /$ www.kmin.ee/sites/default/files/elfinder/article_files/public_opinion_and_national_defence_2018_october_0.pdf, 32; Turu-uuringute, Public Opinion and National Defence, March 2019, 39. Saar Poll, Public Opinion and National Defence, March 2013, http://www.kmin.ee/sites/default/files/elfinder/article_files/public_opinion_and_national_defence_2013_ march.pdf, 30; Saar Poll, Public Opinion and National Defence, October 2013,

${ }^{48}$ WIN/Gallup International, WIN/Gallup International Global Survey Shows Three in Five Willing to Fight for Their Country, 5.

${ }^{49}$ SKDS, Latvijas iedzīvotāju viedoklis par valsts aizsardzības jautājumiem, 42.

${ }^{50}$ Andžāns et al., Psiholoğiskā aizsardzība Latvijā: ievainojamības un iespējas, 17.

${ }^{51}$ Ramonaitè et al., Kas eitu ginti Lietuvos?: pilietinio pasipriešinimo prielaidos ir galimybès.

${ }^{52}$ Kaip minèta tekste, užduodamų klausimų formuluotès skyrèsi. Duomenys pagrịsti šiame tekste nurodytais šaltiniais, išskyrus antrinius šaltinius. Kai kuriais metais buvo įtraukti keli tos pačios šalies tyrimų rezultatai.
} 
Pateiktus rezultatus derètų vertinti šiek tiek atsargiai. Apklausų atlikimo Baltijos šalyse reguliarumas skyrèsi: dažniausiai jos buvo atliekamos Estijoje (turimi 2001-2019 m. lyginamieji metiniai duomenys), rečiausiai - Lietuvoje ir Latvijoje (pavyzdžiui, čia apie didesniają XXI a. pirmojo dešimtmečio dalį neturima jokių duomenų). Be to, atliekant skirtingus tyrimus, respondentams užduodami klausimai ir atsakymų variantai taip pat skyrèsi, dèl to nevienodas duomenų išsamumas. Pavyzdžiui, buvo užduoti bent penki skirtingi klausimai: „Žinoma, visi viliamès, kad karų nebebus, tačiau, jei taip nutiktų, ar būtumète pasiryžęs(-usi) kovoti už savo šalį?" ${ }^{53}$; „Jei kiltų karas, kuriame dalyvautų [šalis], ar būtumète pasiryžęs(-usi) kovoti už savo šalį?" ${ }^{54}$; „Jei [šalis] būtų užpulta, ar esate pasirengęs(-usi) dalyvauti gynybos veikloje, pritaikydamas(-a) savo kompetenciją ir igūdžius?" reiktų, esu pasirengęs(-usi) imtis ginklo ir kovoti, gindamas(-a) [šali]]“56; „Kaip Jūs manote, jeigu [šalis] būtų užpulta, [šalies] gyventojai turètų patys apsiginti ginklu visais atvejais, net kai pasekmès būtų nenusakomos?"57

Tuo pat metu rezultatų apibendrinimo nauda yra didesnè nei minėtasis i̊spejjimas dèl trūkumo. Kaip matome 1 paveikslèlyje, skirtingų apklausu metu surinkti duomenys atspindi iš esmès nuoseklias tendencijas. Tik kai kuriais atvejais pastebima didelių vienos šalies nukrypimų tais pačiais arba kitais metais. Be to, svarbu tai, kad dauguma šių apklausų reprezentuoja atitinkamą nacionalinị lygmenị (daugumą imčių sudaro apie tūkstantis respondentų ir dauguma apklausų buvo atliekamos tiesioginių pokalbių metu).

Matydami 1 paveikslèlyje pavaizduotas tendencijas, galime daryti išvadą, kad daugiausia pasiryžusių ginti savo šali buvo 1990 m., kai visos trys Baltijos šalys ką tik buvo paskelbusios nepriklausomybę nuo Sovietų Sąungos ir patriotiniai jausmai pasiekè visų laikų aukščiausią tašką (oficialiai tarptautinès bendruomenės pripažinta nepriklausomybė pasiekta 1991 m.). Duomenų apie $\mathrm{XX}$ a. dešimtajj dešimtmetị visose trijose šalyse nèra daug, nors turimi duomenys rodo dideli ryžto ginti visas tris šalis sumažèjimą. XXI a. pirmąjị dešimtmeti Estijoje duomenys buvo fiksuojami nuosekliausiai ir dažniausiai - čia apklausos buvo rengiamos kasmet (kartais net tris kartus per metus). Apskritai 1 paveikslèlyje matome, kad aukščiausio lygio pasiryžimas ginti savo šali buvo nuolat stebimas Estijoje, o žemiausio lygio - Lietuvoje ir Latvijoje.

\footnotetext{
${ }^{53}$ European Values Study, EVS 1990 - Variable Report Integrated Dataset, 561; “WVS Wave 6 (2010-2014)”, World Values Survey.

${ }^{54}$ WIN/Gallup International, WIN/Gallup International Global Survey Shows Three in Five Willing to Fight for Their Country, 3.

${ }^{55}$ Estijos gynybos ministerijos vykdyti tyrimai bent nuo 2012 m. Žr. 47 išnašą.

${ }^{56}$ SKDS, Latvijas iedzīvotāju viedoklis par valsts aizsardzības jautājumiem, 42.

${ }^{57}$ Andžāns et al., Psihologiskā aizsardzība Latvijā: ievainojamības un iespējas, 17.
} 


\subsection{Intrasocialinis aspektas $2019 \mathrm{~m}$.}

Kaip pabrèžè Díez-Nicolás, pasiryžimo kovoti už savo šalị lygis dažnai labiau skiriasi vienoje šalyje nei regione ${ }^{58}$. Dèl to šiame skyriuje išsamiai aprašomi ịvairūs veiksniai, turintys ịtakos žmonių pasiryžimui ginti savo šalį, ypač Estiją, Latviją ir Lietuvą.

Visose trijose Baltijos šalyse buvo atlikta reprezentatyvi sociologinè apklausa, siekiant patikrinti šiame straipsnyje nagrinejjamas hipotezes. Iš viso joje dalyvavo 2763 respondentai (atliktų pokalbių skaičius) nuo 18 iki 74 metų: 870 - Estijoje, 1001 - Latvijoje ir 892 - Lietuvoje; respondentų identifikavimui taikytas daugiapakopis proporcingo atstovavimo metodas. Pokalbius Lietuvoje rengè „Baltijos tyrimai“ nuo 2019 m. lapkričio 14 d. iki 2019 m. lapkričio 27 d., Latvijoje - SKDS nuo 2019 m. lapkričio 28 d. iki 2019 m. gruodžio $8 \mathrm{~d}$. , Estijoje - „Turu-uuringute“ nuo $2019 \mathrm{~m}$. lapkričio $28 \mathrm{~d}$. iki tų pačių metų gruodžio $8 \mathrm{~d}$.

Respondentams buvo užduotas šis klausimas: „Kaip Jūs manote, jeigu [Estija, Latvija arba Lietuva] būtų užpulta, [Estijos, Latvijos arba Lietuvos] gyventojai turètų patys apsiginti ginklu visais atvejais, net kai pasekmės būtų nenusakomos?"59 Šis klausimas Švedijoje nuo $1952 \mathrm{~m} .{ }^{60}$ ir Suomijoje nuo 1970 $\mathrm{m}$. apklausose užduodamo klausimo vertimas ${ }^{61}$. Jis taip pat buvo pateiktas $2017 \mathrm{~m}$. Latvijoje atliekant atitinkamą tyrimą ${ }^{62}$.

Palyginti su klausimu, pateiktu Europos vertybiu tyrimo, Pasaulio vertybių apklausos tyrimo ir WIN/ „Gallup International“ visuotinès apklausos metu, šiuo klausimu pabréžiamas gynybinis veiklos pobūdis. Antra, jame minima galimybė apsiginti ginklu, nors tai nereiškia, kad šalị galima apginti tik ginklais (žinoma, yra daugybė panašios svarbos nekarinès veiklos), todèl taip tikrinamos galutinès respondentų ketinimų ribos. Apsigynimo ginklu sąvo-

\footnotetext{
${ }^{58}$ Díez-Nicolás, “Cultural Differences on Values about Conflict, War and Peace”, 264.

${ }^{59}$ Klausimas estų kalba - „Kui Eestit rünnataks, kas siis Teie arvates peaksid Eesti elanikud end igal juhul kaitsma, relv käes, isegi kui tulemus paistaks ebakindel?“; latvių kalba - „Ja Latvijai uzbruktu, vai Latvijas iedzīvotājiem, Jūsuprāt, būtu ar ieročiem jāaizstāv sevi visās situācijās, pat tad, ja iznākums šḳistu neskaidrs?“; lietuvių kalba - „Kaip Jūs manote, jeigu Lietuva būtų užpulta, Lietuvos gyventojai turètų patys apsiginti ginklu visais atvejais, net kai pasekmès būtų nenusakomos?"; rusų kalba (klausta Estijoje ir Latvijoje) - „Если бы на Эстонию напали, на Ваш взгляд, жителям Эстонии надо было бы защищать себя с оружием в руках в любых ситуациях, даже тогда, когда исход был бы неясен?“

${ }^{60}$ Klausimas švedų kalba - „Antag att Sverige anfalls. Tycker du att vi bör göra väpnat motstånd även om utgången för oss verkar oviss?" (Swedish Civil Contingencies Agency, Opinioner 2012, https://www.msb. se/RibData/Filer/pdf/26586.pdf, 85.)

${ }^{61}$ Klausimas suomių kalba - „Jos Suomeen hyökätään, niin olisiko suomalaisten mielestänne puolustauduttava aseellisesti kaikissa tilanteissa, vaikka tulos näyttäisi epävarmalta?" ("Willingness to defend the country”, Statistics Finland, last modified December 14, 2018, https://findikaattori.fi/en/77). ${ }^{62}$ Andžāns et al., Psihologiskā aizsardzība Latvijā: ievainojamības un iespējas, 17.
} 
ka taip pat vartota Latvijos ir Estijos gynybos ministerijų tikslais atliktose apklausose (kaip jau minejjome, Estijoje apklausos atliekamos dažniausiai iš visų Baltijos šalių). Trečia, respondentams pateiktame klausime daroma prielaida, kad galimo puolimo pasekmés yra nenusakomos, taip vélgi siekiant patikrinti galutines respondentų ketinimų ribas.

2 paveikslèlyje pateikti šios apklausos rezultatai rodo panašias tendencijas, kaip ir tos, kurios buvo nustatytos ankstesnių tyrimų metu. Pasiryžimas ginti savo šali yra didžiausias Estijoje (66 procentai), toks lygis yra panašus i Šiaurès šalių demonstruojamą lygit ${ }^{63}$. Pasiryžimas ginti savo šali yra mažiausias Lietuvoje (30 procentų), taigi Latvija lieka viduryje (48 procentai). Estijoje taip pat yra mažiausiai respondentų, negalejusių pateikti atsakymo, patvirtinančio arba paneigiančio toki pasiryžimą (jie sudaro 11 procentų, o tai yra beveik dukart daugiau nei Latvijoje ir Lietuvoje).

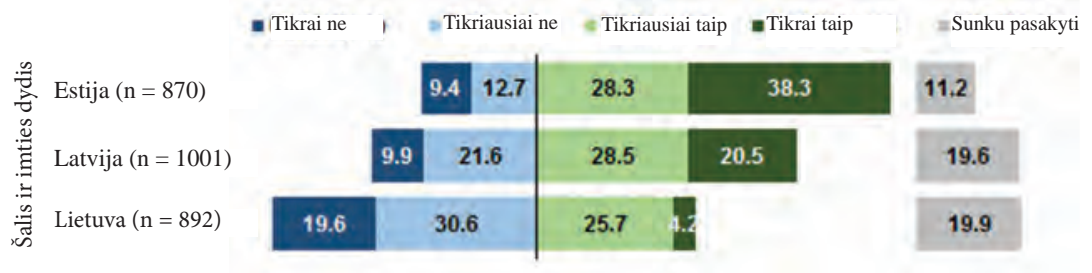

2 pav. Pasiryžimas ginti savo šalị Estijoje, Latvijoje ir Lietuvoje $2019 \mathrm{~m} .{ }^{64}$

Apklausos rezultatai rodo, kad visose trijose šalyse vyrai labiau linkę ginti savo šalị nei respondentės moterys. Panašiai didesnè tikimybè, kad valstybine šalies kalba kalbantys asmenys bus labiau pasiryžę ginti savo šali nei tie, kurie savo šeimose kalba rusiškai. Taip pat yra didesnè tikimybė, kad respondentai, igiję vidurinị arba profesinį vidurinį išsilavinimą, bus labiau pasiryžę ginti savo šalį.

Toliau detaliau pateiksime apklausos duomenis:

- Estijoje vyrai labiau linkę ginti savo šali (72 procentai), palyginti su moterimis (62 procentai); asmenys nuo 64 iki 74 metu (75 procentai), palyginti su 18-24 metų asmenimis (54 procentai); estų kalba kalbantys asmenys (75 procentai), palyginti su rusakalbiais ( 49 procentai); vidurinị arba profesinị vidurinị išsilavinimą igiję asmenys (70 procentų), palyginti su aukštąji išsilavinimą igijusiais asmenimis (61 procentas); Vakarų Estijoje gyvenantys respondentai (79 procentai), palyginti su gyvenančiaisiais šiaurès rytuose (54 procentai);

\footnotetext{
${ }^{63}$ Pvz., 2019 m. atsakymas ị identišką klausimą Suomijoje sudare 68 \% ("Willingness to defend the country", Statistics Finland.)

${ }^{64}$ Atsakymai ị klausimą „Jei [Estija, Latvija ir Lietuva atitinkamai] būtų užpulta, ar [Estijos, Latvijos ir Lietuvos] gyventojai, Jūsų nuomone, turètų imtis ginklų, kad apsigintų visose situacijose, net jei rezultatas neaiškus?"
} 
- Latvijoje vyrai labiau linkę ginti savo šalị (53 procentai), palyginti su moterimis ( 45 procentai); asmenys nuo 45 iki 54 metu (55 procentai), palyginti su 64-74 metų asmenimis (44 procentai); latvių kalba kalbantys asmenys (65 procentai), palyginti su rusakalbiais (40 procentų); vidurinị arba profesinị vidurinị išsilavinimą igiję asmenys (51 procentas), palyginti su aukštaji išsilavinimą igijusiais asmenimis (44 procentai); respondentai, gyvenantys Vidžemès regione (52 procentai), palyginti su gyvenančiaisiais Latgalèje (41 procentas);

- Lietuvoje vyrai labiau linkę ginti savo šalị (36 procentai), palyginti su moterimis ( 25 procentai); asmenys nuo 18 iki 24 metų ( 40 procentų), palyginti su $64-74$ metų asmenimis (26 procentai); lietuvių kalba kalbantys asmenys (30 procentu), palyginti su rusakalbiais (27 procentai); vidurinị arba profesinị vidurinị išsilavinimą igiję asmenys (32 procentai), palyginti su pagrindinị išsilavinimą igijusiais asmenimis (21 procentas); respondentai, gyvenantys Telšių rajone (60 procentų), palyginti su gyvenančiaisiais Utenos rajone (10 procentų).

\section{Intersocialinès ir intrasocialinès hipotezès ir Baltijos šaliu atvejis}

Pirmoji hipotezè (H.1.1) pagrịsta Ingleharto ir kt. tyrimu, kurio metu buvo parengtas detalių tikrinimo priemonių rinkinys. Pagrindiniai jų priemonių rinkinio rodikliai apima "pasirinkimo galimybes palaikančias vertybes“, „demokratinių laisvių indeksą“" „I ir II galimybių gyvenime indeksą“ ir „tarptautinị bendradarbiavimą ${ }^{\text {"65. }}$.

Šio priemonių rinkinio negalima visapusiškai taikyti Baltijos šalims, nes trūksta patikimų ir nuoseklių duomenų apie pasirinkimo galimybes palaikančias vertybes. „Demokratinių laisvių indeksą“ galima vertinti pagal Laisvès rūmų (angl. Freedom House) teikiamus duomenis, kuriais naudojosi Inglehartas ir kt. Pagal Laisvès rūmų indeksą, visos trys Baltijos šalys yra klasifikuojamos kaip „laisvos“, pradedant nuo 1991 m., išskyrus Latviją nuo 1992 iki 1993 m. ir Estiją 1992 m., kai joms buvo priskirtas „iš dalies laisvų“ šalių statusas. To paties šaltinio duomenys rodo, kad nuo $1991 \mathrm{~m}$. laisvių padaugèjo visose

\footnotetext{
${ }^{65}$ Inglehart et al., "Declining willingness to fight for one's country: The individual-level basis of the long peace", 5-10 (appendix).
} 
trijose šalyse, o Estija ir Lietuva šiuo metu užima aukštesnę vietą nei Latvija ${ }^{66}$. Nors visos trys šalys padare didelę pažangą politinių ir pilietinių teisių srityje, jų piliečių pasiryžimas ginti kiekvieną šalị bendrai sumažéjo (žr. tai rodančias linijas 1 paveikslèlyje). Tačiau daugiau niuansų apimanti analizè kelia klausimų dèl tiesioginès sąsajos tarp „demokratinių laisvių indekso“ ir pasiryžimo ginti savo šalį. Pavyzdžiui, priešingai nei teigiama H.1.1, nepaisant stabilaus ir nuo 2014 m. šiek tiek gerejančio laisvès lygio Estijoje ir Latvijoje, piliečių pasiryžimas ginti šias šalis taip pat šiek tiek padidejo.

„I ir II galimybių gyvenime“ vertinimas - pagal duomenis apie vienam gyventojui tenkantị bendrajj vidaus produktą (toliau - BVP), Gini indeksą, vidutinę gyvenimo trukmę gimimo metu, moterų vaisingumo rodikli, stojančiųjų $\mathfrak{i}$ aukštojo mokslo įstaigas rodiklị ir metus, kuriuos asmuo turi mokytis mokykloje, - rodo stiprų galimybių gyvenime augimą Baltijos šalyse. Taigi pagal trečią (daugiapakopę) Ingleharto ir kt. hipotezę ir H.1.1 taip pat būtų galima prognozuoti, kad pasiryžimas ginti savo šali sumažès (toliau pateikti Pasaulio banko duomenys, siekiant kuo didesnio panašumo i Ingleharto ir kt. [tyrimą] ir užtikrinti vienodumą):

- Nuo 1995 iki 2018 m. vienam gyventojui tenkantis BVP Estijoje padidejo 7,5 karto, Latvijoje -7,8 karto, o Lietuvoje - 8,8 karto (2009 m. vienam gyventojui tenkantis BVP ryškiai sumažejo visose trijose šalyse, 2015 m. šis sumažèjimas buvo ne toks ryškus). Pasaulio bankas visas tris šalis priskiria didelių pajamų grupei ${ }^{67}$.

- Nuo 1993 iki 2015 m. nelygybè sumažèjo Estijoje 6,8 Gini taško, o Latvijoje ir Lietuvoje ji padidejo atitinkamai 7,2 ir 3,8 Gini taško ${ }^{68}$.

- Vidutinè gyvenimo trukmé gimimo metu pailgèjo visose trijose šalyse: nuo 1991 iki 2017 m. Estijoje ji pailgejo 10,6 procento, Latvijoje - 7,6 procento, o Lietuvoje - 5,8 procento (nuo 1991 iki $1994 \mathrm{~m}$. visose trijose šalyse nustatytas jos trumpejimas $)^{69}$.

- Moterų vaisingumo rodiklis sumažejo visose trijose šalyse: nuo $1991 \mathrm{iki}$ 2017 m. Estijoje jis sumažèjo 11,1 procento, Latvijoje - 6,5 procento, o

\footnotetext{
${ }^{66}$ Freedom House, HISTORICAL FIW STATUS AND RATINGS INFORMATION, https://freedomhouse. org/sites/default/files/Country\%20and\%20Territory\%20Ratings\%20and\%20Statuses\%20FIW1973-2018. xlsx; "Freedom in the World 2019", Freedom House, accessed December 27, 2019, https://freedomhouse. org/report/freedom-world/freedom-world-2019.

${ }_{67}$ "GDP per capita (current US\$)", World Bank, accessed December 27, 2019, https://data.worldbank.org/ indicator/NY.GDP.PCAP.CD

${ }_{68}$ "GINI index (World Bank estimate)", World Bank, accessed December 27, 2019, https://data.worldbank. org/indicator/SI.POV.GINI

69 "Life expectancy at birth, total (years)", World Bank, accessed December 27, 2019, https://data. worldbank.org/indicator/SP.DYN.LE00.IN
} 
Lietuvoje - 15,9 procento (visose trijose šalyse jis žymiai sumažejo XX a. dešimtojo dešimtmečio pradžioje ir pradejjo didèti nuo $2005 \mathrm{~m}$., o tada vèl nuo $2013 \mathrm{~m}$. ${ }^{70}$.

- Stojančiųjų i mokyklas rodiklis pakilo visose trijose šalyse: nuo 1991 iki $2017 \mathrm{~m}$. Estijoje jis padidejo 45,3 procento, Latvijoje - 62,4 procento, o Lietuvoje - 40,3 procento (nuo XX a. dešimtojo dešimtmečio vidurio visose trijose šalyse šis rodiklis sparčiai kilo $)^{71}$.

H 1.1 „tarptautinio bendradarbiavimo“ vertinimui taikomas supaprastintas metodas, palyginti su Drehero, Gastono ir Martenso ${ }^{72}$ politinès globalizacijos indeksu, kurị naudojo Inglehartas ir kt. Baltijos šalių atveju tiketinos išvados savaime suprantamos, nes visos trys šalys puikiai integravosi $\underset{i}{\text { tarptau- }}$ tinio bendradarbiavimo sriti, ypač nuo 2004 m. Jos yra NATO, ES, Ekonominio bendradarbiavimo ir plètros organizacijos (toliau - EBPO) ir ịvairių kitų regioninių ir pasaulinių organizacijų narès; visos trys šalys pirmininkavo ES Tarybai, o dvi iš jų buvo išrinktos ị Jungtinių Tautų Saugumo Tarybą; visos trys šalys aktyviai dalyvauja karinèse ir civilinèse misijose ir operacijose užsienyje ir priima kitų NATO šalių ginkluotąsias pajegas.

Kalbant apie H.1.1, galima daryti išvadą, kad visos trys Baltijos šalys nuo XX a. dešimtojo dešimtmečio pradžios patyrè spartų galimybių gyvenime augimą, kurị atspindi duomenys apie vienam gyventojui tenkantị BVP, tikètiną gyvenimo trukmę, moterų vaisingumo rodiklị, stojančiųjų ił mokyklas rodikli (vienintelis neịtikinamas visų trijų šalių rodiklis yra ekonominè nelygybė, kuri sumažèjo tik Estijoje). Iš tiesų, kaip prognozuojama H.1.1, turint didesnes galimybes gyvenime, gyventojų pasiryžimas ginti šias šalis sumažèjo nuo XX a. dešimtojo dešimtmečio pradžios (žr. 1 pav.). Vis dèlto turima labai mažai duomenų apie pasiryžimą ginti savo šalị XX a. dešimtojo dešimtmečio pradžioje, o jie būdingi kiekvienam atvejui. Be to, kai kurių rodiklių duomenų svyravimai tam tikrais metais nebūtinai lemia arba žemesnị, arba aukštesnị pasiryžimo ginti šias šalis lygị. Taip pat Estijos ir Latvijos gyventojų pasiryžimas ginti savo šalis nežymiai, bet nuolat didejo nuo maždaug 2014 m., nors ir toliau didejjo galimybès gyvenime.

Remiantis H.1.2, atrodytų, kad visuomenès, kurioms būdingas didesnis nacionalinis pasididžiavimas ir pasitikèjimas nacionalinėmis ginkluotosiomis

\footnotetext{
70 "Fertility rate, total (births per woman)", World Bank, accessed December 27, 2019, https://data. worldbank.org/indicator/SP.DYN.TFRT.IN

71 "School enrollment, tertiary (\% gross)", World Bank, accessed December 27, 2019, https://data. worldbank.org/indicator/SE.TER.ENRR

${ }^{72}$ Axel Dreher, Noel Gaston, and Pim Martens, Measuring Globalisation: Gauging its Consequences (New York: Springer, 2008).
} 
pajėgomis ir vyriausybe, demonstruoja aukštesnio lygio pasiryžimą kovoti. Sąsajos tarp pasiryžimo ginti savo šalį ir nacionalinio pasididžiavimo nustatymą riboja reprezentacinių duomenų, gautų atliekant visų trijų atvejų tyrimus, stoka. Lengviau galima patikrinti artimą sąsają su pasitikejjimu ginkluotosiomis pajėgomis ir vyriausybe. „Eurostat“ duomenimis, didžiausias pasitikèjimas nacionalinèmis ginkluotosiomis pajègomis pastebètas Estijoje $2019 \mathrm{~m}$. jis siekè 82 procentus (jis nuolat išliko aukštas nuo 2004 m. iki 2019 m. ir svyravo nuo 72 iki 82 procentų). Žemesnio lygio pasitikejimas nustatytas Lietuvoje, kurioje jis siekia 77 procentus, ir Latvijoje, kurioje jis siekia 68 procentus (šis rodiklis atitinkamai svyravo nuo 45 procentų 2009 m. iki 77 procentų 2019 m. ir nuo 44 procentų 2009 m. iki 70 procentų 2019 m.; tik Latvijos rodiklis yra žemesnis nei ES vidurkis) ${ }^{73}$. Palyginti su pasitikèjimu nacionalinėmis ginkluotosiomis pajègomis, situacija skiriasi dèl pasitikejimo nacionalinèmis valdžios institucijomis. Visose trijose šalyse vertès yra gerokai žemesnès, palyginti su pasitikejjimu ginkluotosiomis pajègomis. Dabartinis aukščiausias lygis nustatytas Estijoje, kurioje jis siekia 46 procentus (žemiausiais lygis užfiksuotas 2012 m., kai jis sudare 34 procentus, aukščiausias lygis - 2007 m., kai jis sudare 66 procentus), ir Lietuvoje, kurioje jis taip pat siekia 46 procentus (čia žemiausiais lygis užfiksuotas 2010 m., kai jis sudarè 13 procentų, aukščiausias lygis - 2019 m., kai jis sudare 46 procentus), nors, retrospektyviai vertinant, Lietuvoje pasiektas aukštas lygis yra labiau išimtis nei normali padètis. Latvijoje šis lygis siekia 31 procentą (svyravo nuo 9 procentų $2009 \mathrm{~m}$. iki 35 procentų $2005 \mathrm{~m}$. $)^{74}$.

Toliau aptariant H.1.2, pažymètina, kad pasitikèjimas ginkluotosiomis pajegomis ir vyriausybe, susijęs su kintamaisiais, turètų būti vertinamas atsargiai. Nors visose trijose Baltijos šalyse pasitikejimas nacionalinèmis ginkluotosiomis pajègomis gana didelis, kiekvienoje iš jų pasitikejjimas atitinkamomis valdžios institucijomis gerokai mažesnis. Vertinant pagal abu rodiklius, aukščiausias pasitikejjimo lygis yra fiksuojamas Estijoje, todèl jis siejamas su aukštesniu pasiryžimo ginti šią šalị lygiu. O Lietuvoje ir Latvijoje yra mažiau paralelių tarp kintamųjų, siejamų su pasitikẻjimu ir pasiryžimu ginti šalị: jei pasitikejimas ginkluotosiomis pajègomis yra palyginti didelis abiejose šalyse, to negalima pasakyti apie pasiryžimą ginti šali, ypač Lietuvoje.

H.1.3 pažymėta, kad praeityje patirtas pažeminimas karuose ir dabar-

\footnotetext{
73 "Public Opinion," European Commission, accessed December 27, 2019, https://ec.europa.eu/ commfrontoffice/publicopinion/index.cfm/Chart/getChart/themeKy/18/groupKy/82

74 "Public Opinion", European Commission, accessed December 27, 2019, https://ec.europa.eu/ commfrontoffice/publicopinion/index.cfm/Chart/getChart/chartType/lineChart//hemeKy/18/ groupKy/98/savFile/54
} 
tinès išorinès grèsmės turi įtakos pasiryžimui ginti savo šalị. Baltijos šalių tiek praeities, tiek šiuolaikiniai veiksniai yra susiję su Rusija. 1940 m. Sovietų Sąjunga okupavo visas tris šalis, o $1991 \mathrm{~m}$. atkūrus nepriklausomybę, jų santykiai su Rusija yra sudètingi. Rusija iš esmès yra laikoma pagrindine grèsme jų nacionaliniam saugumui, ypač nuo tada, kai prasidejo ginkluotas Rusijos ir Ukrainos konfliktas ${ }^{75}$. Vis dèlto poveikis pasiryžimui ginti savo šali nebuvo vienodas visose trijose Baltijos šalyse. 1 paveikslèlyje parodyta, kad pasiryžimas ginti Lietuvą sumažèjo nuo 2014 m., kai prasidejo ginkluotas konfliktas tarp Rusijos ir Ukrainos. Tuo pat metu pasiryžimas ginti Estiją ir Latviją nuo ìvykių Ukrainoje šiek tiek padidejjo. Tai rodo, kad istorija ir dabartiniai konfliktai tikriausiai nèra pagrindiniai veiksniai, prisidedantys prie aukštesnio pasiryžimo ginti šalị lygio. Tai galima paaiškinti kitokiu estų ir latvių kalba kalbančiu asmenų suvokimu, palyginti su rusakalbiais. Tai galima sieti tiek su istorinès atminties skirtumais, tiek su dabartinių socialinių ir politinių procesų suvokimu, kuriuos iš dalies lemia išorinè ittaka vidaus informacijos erdvei ${ }^{76}$.

Remiantis šio straipsnio tikslais atliktos apklausos duomenimis, jei Estijoje ir Latvijoje būtų vertinamas tik latvių ir estų kalba kalbančių asmenų pasiryžimas ginti savo šalį, atitinkamai tiek 75 procentų, tiek 65 procentų rodikliai būtų tarp aukščiausių rodiklių Šiaurès-Baltijos regione ${ }^{77}$. Nors tuo pat metu vertinto Estijos ir Latvijos rusakalbių pasiryžimo ginti savo šalį rodikliai, kurie atitinkamai siekia 49 procentus ir 40 procentų, yra žemesni, jie nèra tarp žemiausių šio regiono kontekste. Jie net yra aukštesni nei bendras lygis Lietuvoje (kurioje skirtumas tarp lietuviškai kalbančių asmenų ir rusakalbių yra tik 3 procentai, palyginti su 26 procentais Estijoje ir 25 procentais Latvijoje). Viena vertus, panašūs skirtumai tarp estų ir latvių kalba kalbančių asmenų ir rusakalbių buvo pastebėti ir atliekant ankstesnį tyrimą ${ }^{78}$.

Minètoji Gini indekso apžvalga sudaro galimybę patikrinti H.1.4, ku-

\footnotetext{
${ }^{75}$ Parliament of Estonia, National Security Concept of the Republic of Estonia; Parliament of Latvia, The National Security Concept; Parliament of Lithuania, National Security Strategy of the Republic of Lithuania. ${ }^{76} \mathrm{Pvz}$., dauguma Latvijos rusakalbiu naudojasi ne tik vietine žiniasklaida rusų kalba, bet ir Rusijos valstybine žiniasklaida, kuriai būdinga antibaltiška ir antivakarietiška politika. $2017 \mathrm{~m}$. atlikus sociologinius tyrimus nustatyta, kad 80 procentų ne latvių (daugiausia rusakalbių) igyja informacijos ir ieško pramogų rusiškuose šaltiniuose, o tarp 12 šaltinių, kuriais labiausiai pasitikima, net 6 yra Rusijos valstybiniai žiniasklaidos produktai (Latvijas Fakti, Latvijas iedzīvotāju medijpratība. Kvantitatīvais pētijums, June 2017, https://www.km.gov.lv/uploads/ckeditor/files/mediju_politika/petijumi/Medijpratiba_ petijuma\%20rezultati_Latvijas\%20Fakti_18_07_2017.pdf, 7, 12.).

${ }^{77} \mathrm{Pvz} ., 2019 \mathrm{~m}$. atsakymas ị identišką klausimą Suomijoje sudare 68 procentus ("Willingness to defend the country", Statistics Finland.).

${ }^{78}$ Turu-uuringute, Public Opinion and National Defence, March 2019, 40 (to be fair, it has to be noted that in Estonia in the first decade of 2000s this difference has been smaller and in some years it has even been reverse); SKDS, Latvijas iedzīvotāju viedoklis par valsts aizsardzības jautājumiem, 43; Andžāns et al., Psihologiskā aizsardzība Latvijā: ievainojamības un iespējas, 17.
} 
rioje teigiama, kad visuomenès, kurioms būdinga didesnè pajamų nelygybė, demonstruoja menkesni pasiryžimą kovoti. Iš anksčiau čia pateiktų duomenų negalima daryti tiesioginių išvadų. Naujausi „Eurostat“ duomenys panašūs ¡ Pasaulio banko pateiktus duomenis, pagal kuriuos Lietuva ir Latvija užima antrą ir trečią vietą tarp ES šalių pagal didžiausią nelygybę, o Estija siekia ES vidurkị ${ }^{79}$; iš esmès panašų vaizdą galima susidaryti pagal EBPO pateiktus duomenis $^{80}$. Iš tiesų Lietuvoje matomas aukščiausias nelygybès ir žemiausias pasiryžimo ginti savo šalị lygis, o Estijoje situacija yra priešinga abiem atžvilgiais. Vis dèlto, lyginant Lietuvą ir Latviją, nedideli nelygybės ir dideli pasiryžimo kovoti skirtumai kelia abejonių dèl H.1.4 pagrịstumo.

Kaip jau nurodème, antroji hipotezių grupè yra susijusi su intrasocialiniu lygmeniu. Nors nèra palyginamų ar nuoseklių duomenų, pagal kuriuos būtų galima patikrinti H.2.2 ir H.2.3 atitinkamai dèl nelygybès ir žmonių sprendimų racionalumo, turima daugiau duomenų apie H.2.1 minimus veiksnius. Šiame straipsnyje patvirtinama H.2.1, kalbant apie tai, kad vyrai labiau linkę ginti savo šalį nei respondentės moterys. Akivaizdu, kad tam turèjo ịtakos išlikęs suvokimas, kad gynyba ir saugumas visų pirma yra vyriškos veiklos sritis. Kitaip išvados apie intrasocialines hipotezes iš dalies patvirtina Rutkausko parengtus rezultatus, šiam padarius išvadą, kad nacionalinis pasididžiavimas ir pasitikejjimas tiek ginkluotosiomis pajègomis, tiek valdžios institucijomis yra reikšmingi veiksniai, turintys ịtakos asmens pasiryžimui ginti savo šali visose trijose šalyse $^{81}$. Nors tai šiek tiek galima pastebèti analizuojant Estijos duomenis, kitose dviejose šalyse šios paralelès nèra tokios aiškios. Be to, akivaizdžiai skiriasi visų trijų šalių piliečių pasitikejjimas ginkluotosiomis pajėgomis ir kitomis valstybès institucijomis.

Jau minėjome, kad kartu su lyties klausimu įvairiose išvadose yra aptariami ir veiksniai, susiję su amžiumi, išsilavinimu, religingumu, ideologinèmis pažiūromis, karo prievole, kaip turintys įtakos pasiryžimui ginti savo šalị. Nei Rutkauskui, nei mums 2019 m. atlikus apklausą, nenustatytas nekintamas ryšys, siejamas su pasiryžimu ginti savo šalị, visose trijose šalyse, neatsižvelgiant j̇ amžių ir išsilavinimą. Rutkauskas atkreipé dėmesĭ, kad Estijoje ir Lietuvoje vyresnio amžiaus žmonès buvo mažiau pasiryžę ginti savo šali, o Latvijoje situacija buvo priešinga; atlikus apklausą, nustatyta, kad vyresnio amžiaus estai labiau pasiryžę ginti savo šalị. Dèl išsilavinimo Rutkauskas padare išvadą, kad

\footnotetext{
79 "Gini coefficient of equivalised disposable income - EU-SILC survey", Eurostat, accessed December 27, 2019, https://appsso.eurostat.ec.europa.eu/nui/submitViewTableAction.do

80 "Income inequality", Organisation for Economic Co-operation and Development, accessed December 27, 2019, https://data.oecd.org/inequality/income-inequality.htm

${ }^{81}$ Rutkauskas, "Factors Affecting Willingness to Fight for One’s Own Country: The Case of Baltic States", 60.
} 
Lietuvoje ir Latvijoje labiau išsilavinę respondentai yra labiau pasiryžę kovoti, nei Estijoje ${ }^{82}$, čia buvo nustatyta, kad visose trijose šalyse vidurinị arba profesini vidurinị išsilavinimą turintys asmenys buvo labiausiai pasiryžę ginti savo šalis.

Religingumo poveikis vèlgi yra sunkiai patikrinamas dèl sekuliarizacijos ir nepatikimų duomenų. Estija nuolat priskiriama prie mažiausiai religingu pasaulio šalių, nors ir kitos dvi šalys taip pat nèra laikomos itin religingomis ${ }^{83}$. Sekuliarizaciją Estijoje patvirtina naujausio gyventojų surašymo duomenys, nes tik 29 procentai gyventojų išpažizsta tam tikrą religiją (16 procentų respondentų išpažįsta stačiatikybę, 10 procentų - liuteronybę) ${ }^{84}$. Naujausio Lietuvos gyventojų surašymo duomenys rodo, kad 77,2 procento gyventojų nurodo esantys Romos katalikai ${ }^{85}$. Klausimai apie religiją nebuvo ịtraukti ị naujausią Latvijos gyventojų surašymą, kituose oficialiuose šaltiniuose tèra pateikiama informacija apie religinių kongregacijų skaičių (iš visų kongregacijų daugiausiai yra liuteronų, Romos katalikų ir stačiatikių ${ }^{86}$. Situacijos vertinimą apsunkina ir tai, kad reali situacija gali dar labiau skirtis, nes net ir religiją išpažịstančių asmenų pasiryžimas ginti savo šali gali skirtis. Kita vertus, nederètų nuvertinti buvusio ir dabartinio religinių vertybių poveikio net pasaulietinėms visuomenèms. Kaip ir per daugumą apklausų, ịskaitant šio straipsnio tikslais atliktą apklausą, negalejome nustatyti tiesioginès sąsajos tarp religijos ir pasiryžimo ginti savo šalị. Galime tik daryti bendras prielaidas, pagrịstas atskirai gautais duomenimis, susiejančiais pasiryžimą ginti savo šali ir religiją.

Paskutinis, bet ne mažiau svarbus yra karo prievolès klausimas, neseniai ịtrauktas ị Baltijos šalių planą dèl išorinių grèsmių. Estijoje ir Lietuvoje taikomi skirtingi karo prievolès modeliai (Lietuvoje ji vèl buvo ịvesta $2015 \mathrm{~m}$., taip reaguojant ị Rusijos ir Ukrainos ginkluotą konfliktą), o Latvijoje buvo panaikinta 2007 m. ir nuo tada nebeatnaujinta. Pagal 1 paveikslèlyje pavaizduotus pasiryžimo ginti savo šalị lygius negalima nustatyti ịtikinamų dėsningumų

\footnotetext{
${ }^{82}$ Rutkauskas, "Factors Affecting Willingness to Fight for One's Own Country: The Case of Baltic States", 57-61.

83 “Least Religious Countries 2020," World Population Review, last modified November 6, 2019, http:// worldpopulationreview.com/countries/least-religious-countries/; "How do European countries differ in religious commitment? Use our interactive map to find out", Pew Research Center, last modified December 5, 2018, https://www.pewresearch.org/fact-tank/2018/12/05/how-do-european-countries-differ-inreligious-commitment/ 84 "PHC 2011: OVER A QUARTER OF THE POPULATION ARE AFFILIATED WITH A PARTICULAR RELIGION”, Statistics Estonia, last modified April 29, 2013, https://www.stat.ee/news-release-2013050 ?highlight=religion

85 "Ethnicity, mother tongue and religion", Statistics Lithuania, last modified March 15, 2013, https://osp. stat.gov.lt/en/web/guest/informaciniai-pranesimai?articleId=223122

${ }^{86}$ Central Statistical Bureau of Latvia, Statistical Yearbook of Latvia, 2020, https://www.csb.gov.lv/ sites/default/files/publication/2019-12/Nr_01_Latvijas_statistikas_gadagramata_2019_Statistical\%20 Yearbook\%20of\%20Latvia_\%2819_00\%29_LV_EN.pdf, 112.
} 
visose trijose šalyse. Estijoje, kur karo prievolè sulaukia didelio visuomenès palaikymo ${ }^{87}$, pasiryžimas ginti savo šalị yra didelis, Lietuvoje - mažas, o nuo karo prievolès grąžinimo dar labiau sumažèjo.

\section{Išvados}

Pasiryžimo ginti savo šalị klausimas - svarbi diskusijų apie šalies gynybą ir visuomenès saugumą dalis. Pasiryžimo mastas ir stiprumas yra ịvairių visuomenès lygių ir individualaus lygmens požiūrio į atitinkamų šalių politinius, visuomenès ir ekonominius procesus požymis ir veiksnys. Asmens pasiryžimas tiesiogiai siejamas su visuomenès atsparumu ir galimybe priešintis išorinėms ir vidaus grèsmèms ir iššūkiams. Diskusijos apie asmens prioritetus ir pasirinkimus saugumo kontekste yra išsamios ir ekstensyvios ir apima ne tik karini sektorių. Atsižvelgiant ị galimybes ir iššǔkius, siejamus su skaitmenizacija ir skaitmeninès informacijos erdvès, kaip ginklo, pritaikymu, pasiryžimą ginti savo šalị veikia netyčiniai ir iš anksto apgalvoti ịtakos veiksniai, pradedant nuo labiau ịvairiapusio požiūrio ị situaciją šalyje ir baigiant išoriniais bandymais sumažinti pasitikejimą ir pasiryžimą ginti tą šalị. Vertybių sistemos, politinis pagrịstumas, patriotizmo suvokimas ir praktika, demokratinių institucijų efektyvumas yra vieni svarbiausių kintamųjų, prisidedančiu prie visuomenès atsparumo ir formuojančių specifines individualias nuostatas, ịskaitant pasiryžimą ginti savo šalị.

Šiame straipsnyje apžvelgiami ir pateikiami empiriniai duomenys, siekiant patikrinti kelias hipotezes apie pasiryžimą ginti savo šalį ar jo stoką. Jos buvo suskirstytos ị intersocialinę ir intrasocialinę kategorijas. Jos buvo patikrintos Estijos, Latvijos ir Lietuvos atveju kartu su kitais veiksniais, kurie gali turèti ịtakos pasiryžimui ginti savo šalị. Tarp apžvelgtų veiksnių buvo galimybės gyvenime, pasitikẻjimas ginkluotosiomis pajègomis ir vyriausybe, istorija ir išorinès grèsmès, pajamų nelygybè, lytis, religingumas, amžius, išsilavinimas ir karo prievolè.

Per tris dešimtmečius atliktos daugkartinès apklausas rodo, kad iš Baltijos šalių pasiryžimas ginti savo šalị yra didžiausias Estijos, o mažiausias - Lietuvos gyventojų. Baltijos šalių tyrimas iš esmès patvirtina hipotezę, kad galimybiu gyvenime didejjimas turi neigiamą ittaką plačiai paplitusiam pasiryžimui ginti savo šalị. Vis dèlto kiekvienai šaliai būdinga tam tikra specifika ir trajektorijos. Aukštas pasiryžimo lygis Estijoje kartu su sparčiu galimybių gyvenime

${ }^{87}$ Turu-uuringute, Public Opinion and National Defence, March 2019, 52. 
augimu, vykusiu tris pastaruosius dešimtmečius, siejamas su panašiais kitų mokslininkų pastebejimais tiriant Šiaurès šalis, kuriose pasiryžimas kovoti yra didelis, nepaisant didesnių galimybių gyvenime. Vis dèlto galimybių gyvenime augimu negalima paaiškinti Baltijos piliečių pasiryžimo ginti savo šalis lygio svyravimų, ypač Lietuvos atveju.

Trijų šalių rezultatų, susijusių su pasiryžimu ginti savo šalį, skirtumai, išskyrus tam tikras išimtis, susijusias su galimybèmis gyvenime ir lytimi, leidžia daryti išvadą, kad, nepaisant tam tikrų bendrų pasaulinių ir regioninių tendencijų, pasiryžimas ginti savo šalị priklauso nuo veiksnių, kurie labiau būdingi konkrečiai šaliai nei konkrečiam regionui, derinio. Be to, intersocialinių ir intrasocialinių veiksnių deriniai nèra nusistoveję ir, laikui bėgant, kinta. Taigi, ateityje atliekant tyrimus, būtų galima naudoti konkrečiam atvejui pritaikytus modelius ir išsamesnes metodikas, siekiant nustatyti specifinius ir dinaminius priežastinius mechanizmus, kuriais grindžiami žmonių prioritetai ir motyvacija ginti savo šalị, taip pat plètoti bendresnius svarstymus, orientuotus i asmens pasiryžimo ginti savo šalị ir besivystančių demokratinių visuomenių pobūdžio ir jų patiriamų iššǔkių sąsają ir sinergiją.

2019 m. gruodis 